\title{
Bilateral protrusio acetabuli of the hip
}

Raju Vaishya

Department of Orthopaedic and Joint Replacement Surgery, Indraprastha Apollo Hospitals, New Delhi, Delhi, India

\section{Correspondence to} Professor Raju Vaishya, raju.vaishya@gmail.com

Accepted 11 February 2014

\section{CrossMark}

To cite: Vaishya R. BMJ Case Rep Published online: [please include Day Month Year] doi:10.1136/bcr-2013201784

\section{DESCRIPTION}

A 65-year-old woman presented with a 20-year history of seropositive rheumatoid polyarthritis. Her disease had destroyed most of her major joints of the body, including both knees, hips, elbows, wrists, finger joints, spine and joints of the feet. She had undergone a successful bilateral total knee replacement surgery 7 years ago.

For the past 2 years, she had been having difficulty in standing and walking with 'noises' coming from both hip joints. An X-ray of the pelvis (anteroposterior view) showed severe bilateral hip arthritis (figure 1) with migration of the femoral head $(\mathrm{R}>\mathrm{L})$ into the pelvis (protrusio acetabuli). She had undergone a bilateral simultaneous total hip replacement surgery (figure 2) 6 months ago. The surgery was performed as a single-stage procedure using hybrid hip prosthesis on both sides, where a cemented femoral stem (Exeter stem) and an uncemented cup were used with impaction bone grafting of the acetabulum. She is now pain free and is able to walk and stand comfortably.

Protrusio acetabuli is a condition of the hip where there is medial displacement of the femoral head into the pelvis and the medial aspect of the femoral head lies medial to the ilioischial line. ${ }^{1}$ Protrusio acetabuli could be primary or secondary. Bilateral condition could be found in conditions such as rheumatoid arthritis, Paget's disease, ankylosing spondylitis, Marfan's syndrome and osteomalacia. The joint replacement surgery is usually necessary in cases of severe pain or substantial joint restriction owing to secondary hip arthritis. ${ }^{23}$

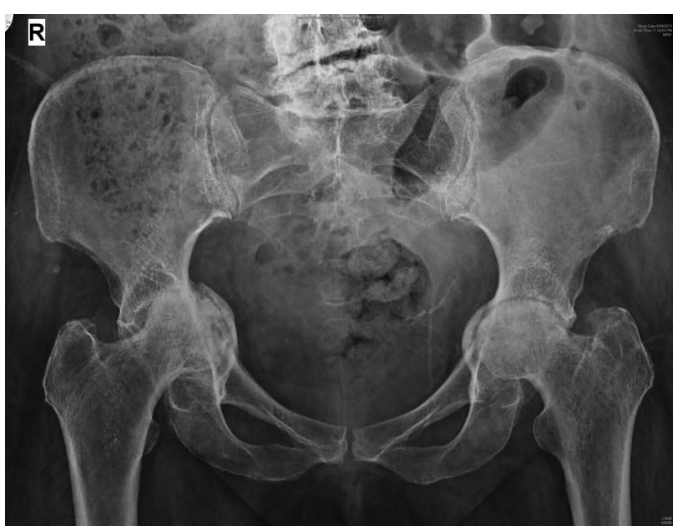

Figure 1 Preoperative X-ray of the pelvis showing bilateral hip arthritis and severe protrusio acetabuli.

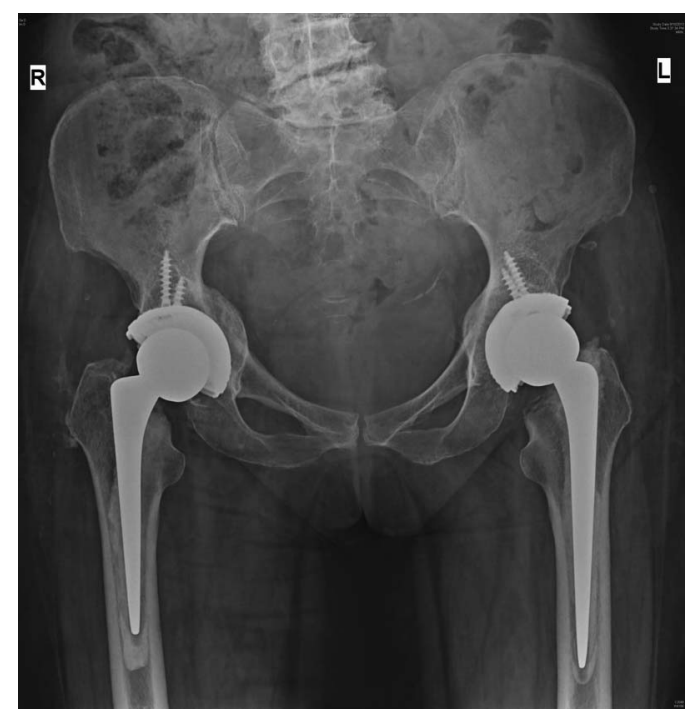

Figure 2 Postoperative X-ray showing bilateral total hip replacements, in situ.

\section{Learning points}

- Rheumatoid arthritis can present with bilateral protrusio acetabuli of the hip.

- Severe bilateral hip arthritis can be treated effectively by a simultaneous total hip replacement surgery.

- Protrusio acetabuli is a condition where there is medial migration of the femoral head into the pelvis.

Competing interests None.

Patient consent Obtained.

Provenance and peer review Not commissioned; externally peer reviewed.

\section{REFERENCES}

1 Van De Velde S, Fillman R, Yandow S. The aetiology of protrusio acetabuli. Literature review from 1824 to 2006. Acta Orthop Belg 2006:72:524-9.

2 McBride MT, Muldoon MP, Santore RF, et al. Protrusio acetabuli: diagnosis and treatment. J Am Acad Orthop Surg 2001;9:79-88.

3 Ranawat CS, Dorr LD, Inglis AE. Total hip arthroplasty in protrusio acetabuli of rheumatoid arthritis. J Bone Joint Surg Am 1980;62:1059-65. 
Copyright 2014 BMJ Publishing Group. All rights reserved. For permission to reuse any of this content visit http://group.bmj.com/group/rights-licensing/permissions.

BMJ Case Report Fellows may re-use this article for personal use and teaching without any further permission.

Become a Fellow of BMJ Case Reports today and you can:

- Submit as many cases as you like

- Enjoy fast sympathetic peer review and rapid publication of accepted articles

- Access all the published articles

- Re-use any of the published material for personal use and teaching without further permission

For information on Institutional Fellowships contact consortiasales@bmjgroup.com

Visit casereports.bmj.com for more articles like this and to become a Fellow 